EDITORIAL

\title{
Efek sinar biru pada kornea, lensa dan retina
}

\author{
Husnun Amalia \\ Departemen Ilmu Penyakit Mata, Fakultas Kedokteran Universitas Trisakti \\ Email: husnun_a@trisakti.ac.id
}

Gawai (gadget) adalah media elektronik yang sangat tinggi penggunaannya saat ini. ${ }^{(1)}$ Penggunaan gawai meningkat dari 3 juta orang (tahun 1990) menjadi 2.2 miliar (tahun 2011). Pada usia anak-anak dan dewasa dilaporkan menggunakan gawai hingga 7 jam/hari. ${ }^{(2,3)}$ Media elektronik ini menggunakan teknologi sinar biru yang dapat mempengaruhi dan membahayakan kesehatan mata. Cahaya dengan panjang gelombang antara 300-400 $\mathrm{nm}$ dapat menembus kornea dan diserap oleh iris atau pupil. Sinar biru gelombang pendek berenergi tinggi dengan panjang gelombang 415 dan $455 \mathrm{~nm}$ adalah yang paling berbahaya untuk mata. ${ }^{(1)}$ Selain itu, sinar dengan panjang gelombang 400-460 nm lebih berbahaya daripada sinar dengan panjang gelombang $470-490 \mathrm{~nm} .{ }^{(4)}$

Pengaruh sinar ini ditentukan oleh panjang gelombang, frekuensi dan lama paparan.

(2) Sinar biru dapat mempengaruhi kesehatan kornea, lensa dan retina. Pada kornea sinar ini dapat mengakibatkan kerusakan sel epitel melalui peningkatan produksi Reactive Oxigen Species (ROS) pada epitel kornea yang selanjutnya terjadi kerusakan akibatreaksioksidatifdanapoptosisyang memicu peradangan dan terjadinya Xeropthalmia. Saat ini dikenal dengan dry eye atau mata kering dan dapat diatasi dengan pelembab tetes mata yang mengandung antioksidan. ${ }^{(1)}$ Nirwano $\mathrm{Y}$ et al menemukan adanya phototoxicity sinar biru akan mengganggu fase mitosis epitel kornea. ${ }^{(5)}$ Kerusakan juga dapat terjadi pada mikrovili epitel kornea sehingga mengganggu fungsinya sebagai perekat dan menstabilkan lapisan air mata dan hal ini mengakibatkan terjadinya dry eye. Sinar biru juga dapat menghambat aktifitas biokimia pada stroma kornea. ${ }^{(1)}$

Struktur lensa mata manusia mengandung protein yang berperan dalam penyerapan sinar biru. Selanjutnya akan terbentuk pigmen kuning pada protein tersebut, yang akan mengubah lensa menjadi lebih gelap dan kekuningan. Proses ini berfungsi untuk menghentikan pengaruh sinar biru agar tidak mencapai retina dan menyebabkan kerusakan. Selain itu sinar biru akan menginduksi pembentukan ROS dalam mitokondria epitel lensa yang menimbulkan oksidatif stres dan kerusakan oksidatif pada lensa. Kedua hal ini yang akan memulai proses pembentukan katarak. Oksidatif stres dapat dihambat oleh antioksidan. Pada lensa terdapat dua antioksidan yaitu Lutein dan Zeaxanthin yang dapat melindungi protein, lipid dan DNA lensa dari kerusakan akibat oksidatif stres. $^{(1)}$

Kornea dan lensa adalah barrier yang mencegah proses masuknya sinar biru mencapai retina. ${ }^{(4)}$ Karena sinar ini akan menyebabkan kerusakan fotokimia yang irreversibel. ${ }^{(1)}$ Hal ini dapat dicegah melalui penggunaan kacamata atau intraokular lens yang berwarna kuning yang akan memberikan perlindungan dari sinar dengan panjang gelombang 400-450 nm. ${ }^{(4)}$ Bila sinar mencapai retina akan mengaktivasi sel mikroglia yang kemudian akan bermigrasi dan menfagosit fragmen lapisan inti luar retina sehingga terjadi kematian sel. Hal ini mempercepat proses terjadinya Age Related Macular Gegeneration (ARMD). Beberapa penelitian menyatakan paparan sinar biru dapat mempercepat pembentukan ARMD setelah dilakukan operasi katarak, walaupun operasi katarak tersebut telah dilakukan sejak beberapa tahun yang lalu. ${ }^{(1)}$

Sinar ini juga dapat menyebabkan kerusakan pada sel kerucut dan akan menstimulasi munculnya sel makrofag dan mengaktivasi mikroglia. Selanjutnya akan menyebabkan gangguan fungsi pada barrier darah retina karena diproduksi berbagai faktor pro-inflammatory yang juga menyebabkan edema retina, peningkatan permeabilitas pembuluh darah dan diekstruksinya 
komponen kompleks imun dan limfotoksin. Sehingga mengakibatkan degenerasi dari sel fotoreseptor. Sinar ini juga menimbulkan oksidatif stres pada retina yang mengakibatkan apoptosis dan nekrosis sel fotoreseptor dan sel epitel pigmen retina. $^{(1)}$

Paparan sinar biru saat malam hari akan menstimulasi otak sehingga terjadi hambatan pada sekresi melatonin, yang kemudian akan meningkatkan produksi kortikosteroid, lalu terjadi gangguan sekresi hormon dan secara langsung akan mempengaruhi kualitas tidur. ${ }^{(6)}$ Gangguan tidur akan menurunkan kadar androgen dalam tubuh dan berakibat gangguan pada fungsi kelenjar pada palpebra. Hal ini membuat penurunan sekresi kelenjar meibom dan berakibat terjadinya evaporasi berlebihan sehingga akan terjadi $d r y$ eye. ${ }^{(1)}$

Penggunaan gawaiyangmengandung sinar biru dengan durasi tertentu dapat menyebabkan kelelahan mata sehingga sebaiknya pengguna dapat lebih bijaksana dalam menggunakan gawai untuk mencegah terjadinya kelelahan pada mata. ${ }^{(7)}$ Mencegah dan mengontrol kerusakan yang diakibatkan oleh sinar biru merupakan hal yang sangat penting. Hal yang dapat dilakukan adalah dengan menggunakan filter sinar biru pada media elektronik atau kacamata anti sinar biru, mengurangi penggunaan media elektronik pada malam hari dan mengkonsumsi antioksidan dengan cukup. ${ }^{(1)}$

\section{DAFTAR REFERENSI}

1. Zhao ZC, Zhou Y, Tan G, Li J. Research progress about the effect and prevention of blue light on eyes. Int J Opthalmol 2018; 11(12): 1999-2003. DOI: $10.18240 /$ ijo.2018.12.20

2. Muniraju NM, HK Amarnath, MJ Ashwini. A review on effects of electronic Gadgets on eye. Journal of Ayurveda Physicians \& Surgeons 2018; $5(1)$.

3. Unplagan K, Balasubramaniam B,Premkumar T, Chien JLC, Rao AS, Rasir RASA. Impact of electronic devices on the life of children: A cross sectional study from Ipoh, Perak, Malaysia. Quest International Journal of Medical and Health Sciences 2018; 1(2): 30-4

4. Tosini G, Ferguson I, Tsubota K. Effect of blue light on the circadian system and eye Physiology. Molecular Vision 2016; 22:61-72

5. Niwano Y, Kanno T, Iwasawa A.Blue light injures corneal epithelial cells in the mitotic phase in vitro. Br J Opthalmol 2014; 1-2. DOI: 10.1136/ bjophthalmol-2014-305205.

6. Gabel V, Reichert CF, Maire M, Schmidt C,
Schlangen LJM, Kolodyazhniy V, et al. Differential impact in young and older individuals of blueenriched white light on circadian physiology and alertness during sustained wakefulness. Sci Rep 2017;7(1):7620. DOI:10.1038/s41598-017-070608

7. Rahmat NN, Munawir A, bukhori S. Duration of Gadget usage affects eye fatique in students age 16-18 years. Health Notions 2017; 1(4): 335-40. 